\title{
VISUAL AND INFRARED GRAPHIC APPLIED THROUGH DEDICATED HALFTONING FOR TRANSPARENT POLYPROPYLENE PACKAGING
}

\author{
Martina Friščić, Ana Agić, Ivana Žiljak Stanimirović
}

Original scientific paper

In the security managing of packaging infrared transparent graphics on polypropylene material is involved. Preparing of dual images of objects, textual messages in visual-V and NIR-Z domain is extended with dual separation which defines new flexographic procedures of colour mixing. Profiles describing and defining V and Z twin pairs are strictly associated with printing conditions. Quality of twin pairs is achieved with spectroscopic analysis of measuring light absorption in visual and near infrared spectrum. Halftoning algorithms support transparent flexographic foil that does not absorb printing inks and does not penetrate into the printing media. Line halftoning element with "knee" effect is developed to additionally demonstrate the plasticity of primary objects or letters. The balance between equalizing of inks in the visual domain, and their differentiation in NIR-Z spectral domain is achieved. Relatively coarse shape and structure of screening elements, low ruling, is suitable for additional transparency of graphics, so that the underlying goods packed in foil can be observed. Secondary, hidden graphics is accessible through NIR camera technology. In that way multiple security options are ensured.

Keywords: extended NIR separation; spectroscopy of twin dyes; dedicated knee screening shape; transparent polypropylene wrapping packaging material; security graphics

\section{Vizualne i infracrvene grafike s primjenom namjenskog postupka rastriranja za prozirnu polipropilensku ambalažu}

Izvorni znanstveni članak U sigurnosni sustav ambalaže uvodi se infracrvena transparentna grafika na polipropilenskom materijalu. Priprema dvojnih slika objekata, tekstova u vidljivom-V i NIR-Z području, proširena je dvojnom separacijom koja definira nove fleksotiskarske postupke miješanja bojila. Profili koji opisuju definiraju parove V i Z blizanaca striktno su povezani sa uvjetima tiskarske tehnologije. Kvaliteta blizanaca bojila potvrđuje se spektroskopskim postupcima mjerenja apsorpcije svjetla u vizualnom i infracrvenom spektru. Rasterski algoritmi podržavaju transparentnu foliju za flekso reprodukciju koja ne upija tiskarsku boju i ne penetrira u polipropilenski medij. Razvijen je linijski rasterski algoritam efekta "koljena" koji dodatno potpomaže plastičnosti primarnih objekata ili slova. Postignuta je ravnoteža ujednačenosti bojila u vidljivom spektru kao i njihova različitost u NIR-Z spektru. Relativno gruba struktura rasterskih oblika, niska linijatura, pogodna je za postizanje dodatne transparentnosti grafike kako bi se upakirani sadržaj ispod folije mogao vidjeti. Sekundarna, skrivena slika je dostupna preko tehnologije NIR kamera. Na taj se način osiguravaju višestruke mogućnosti zaštite.

Ključne riječi: proširena infracrvena separacija; spektroskopija blizanaca bojila; koljenasta grafika; transparentni polipropilenski ambalažni materijal, sigurnosna grafika

\section{Introduction}

NIR technology was widely introduced several years ago, widening various aspects in printing security, instrumentally broadening visual area to domain till 1000 $\mathrm{nm}$ [1]. Inventors, designers and technology experts made a lot of effort in that field, which is now being explored worldwide, obtaining different interchange procedures, as by Wang [2], in printing on other kind of transparent materials managing EAN codes in security manner [3]. Recalculating and adjusting operational/colour measurement is a very interesting topic in various printing fields [4]. Developing complex algorithms that connect visual and near infrared domain for unifying sensor information is also in study and progress [5]. Now IR graphic is being introduced in packaging system, in flexo printing on transparent polypropylene material. There are more reasons for such implementation according to specific claims in this field: polypropylene as a material which keeps packaged goods, advertisement and specification printed on the foil in a specific way, ensuring visibility of the goods, and the security of an object or elements setup in NIR system to prevent forgery [6]. Security elements must not be visible in the visual domain.

If the primary visual image or graphic is full tone and colours, a suitable solution might be the usage of standard-common halftoning systems [7]. Various standard or common dot/element shapes, such as round, elliptical, square, diamond, cross, line or wave can be used. Any halftoning system can also influence the secondary image. In any case, designers and technologists have to coordinate the issues with material composition and system choice, with a high level of cognition and understanding. In the case of generated or programmed screening, various screening dedicated systems can be used [8], as well as wide palette of screening element shapes, that can be defined in various ways [9], [10]. Furthermore, printing substrate can cause some screening-printing conditions, as in this case polypropylene foil as substrate, besides appropriate output unit. The transparency of wrapping material is important, so that the customers can see content of the packaged goods. Besides that, the packaging material must contain some important data about the goods inside. So it must be a compromise between printed and non-printed areas, so that basic information can be on the package foil, but also the goods have to be seen through free areas. That situation has to be solved through designer/technologist coordination which means appropriate printing conditions for chosen substrate, polypropylene in this example [11]. That fact includes choice of halftoning system that can preserve adequate transparency in non-printed areas for visibility of packaged goods. Additional transparency adjusted with moderate coverage of elements has to be used. Defined twin pairs independent from other influences ensure in NIR separation secondary image. 
It is not always easy to define what "standard" screening is, because it depends on a variety of parameters. In this example the media is transparent foil, flexo printing output adjusted for polypropylene, and selected screening system that allows modifications and adjusting as well as achieving a stable secondary image. Various element shapes and rulings are mostly in accordance with a printing system, but designer's way-out decisions can be a significant factor in the whole procedure setup as well.

\section{Defining the halftoning elements procedure}

Programming and achieving new, custom screen elements [12] opens new possibilities and perspectives in the realization of various dedicated screening systems, and a variety of technological and designer solutions, also in the near infrared area [13], where not only different element shapes can be defined, but specific micro structure of an element can be achieved.

New custom screening systems realized by functions gave new dimension in the realization and designer aspirations (Fig. 1). Each possible shape can be defined and applied for a dedicated purpose, and such possibilities facilitate enormous range of specific and dedicated solutions to designers.

For the following, a dedicated resource line screen shape model is chosen. At first glance it is a rather simple system, from a subgroup of "effect" screens, that can be performed by translating to vector or pixel graphic programming system. Pure lines are probably not suitable to produce an image of a sufficient quality, they can present "coverage" by line width, but they can be interesting for possible effects and exposing some objects (Fig. 2), that can be incorporated into a larger image. For specific packaging transparent material purposes ruling (covered and non-covered - transparent areas) can be programmed on demand. Of course, standard halftoning rules also have to be obeyed as well.

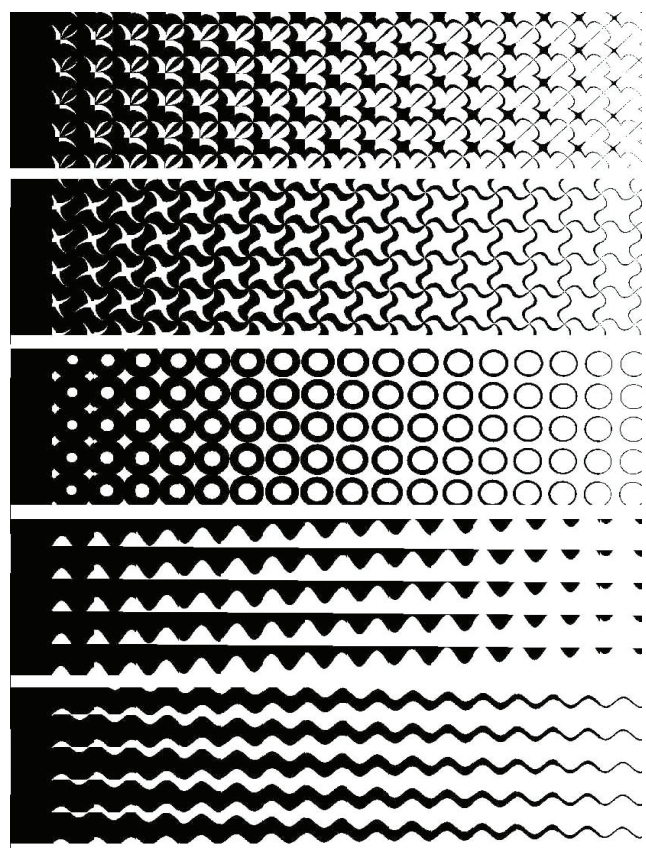

Figure 1 Examples of dedicated programmed series of customized element shapes
This proposed system involves quadruple security features: NIR technology, custom palette defined inks/dyes for twin pairs, "knee" effect screening system and custom designed element shape.

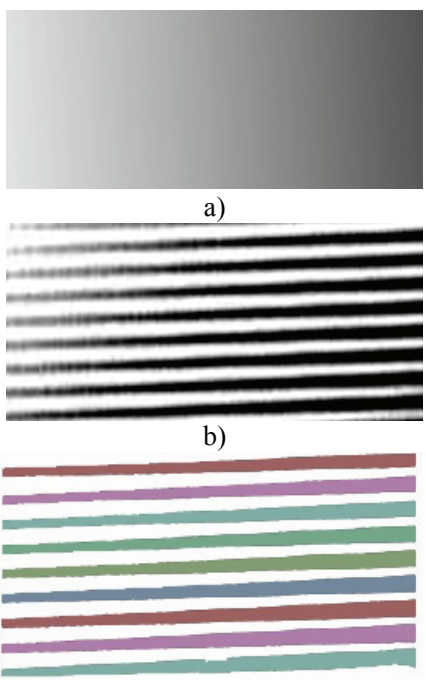

c)

Figure 2 Hi res. "contone" transition as 8-bit depth screen image (a); line transition in low ruling, as printed (b); programmed coloured lines in low ruling, as printed, example (c)

For specific purposes programme modified and customized for dual graphic purposes customized screens can be very suitable. In this case it consists of several parallel lines defined as twin pairs for the purpose of secondary image, and programme supported "knee" module for describing a real or plasticity of primaryvisual object or letters. Simplified perspective principle is applied, achieving the real effect of the primary object.

\section{Dedicated "knee effect lines" halftoning module}

Knee effect lines as a dedicated halftoning system has a feature in which abundance of lines changes along the direction of basic graphic lines, which are equidistance modulated. Objects, fonts (characters) and backplane are presented as a structure of parallel lines with variable width (covered part), and non-covered distances between them. Lines imitate transition between proposed sample tones. This involves translation of pixel graphics into vector graphics. Each single line is coloured with a $\mathrm{V}$ twin. Entering left side (bound) of font or object the line changes its direction and rises up. At that moment the line continues as a $\mathrm{Z}$ twin. Before reaching the above line, it continues horizontally upwards font, until it reaches white background on left side of the font. At that point the line is set down to the starting level and continues horizontally, while system changes from $\mathrm{V}$ twin stage to $\mathrm{Z}$ twin stage. On direction change, the line increases its coverage more than in normal horizontal progress. For visual experience that appears as the "darker" area, enabled by line contrast, therefore such graphic section grants recognition of the observed font. Lines and their mutual distance determine coverage of the whole security graphics, transparency degree and stochastic colour changes according to INFRARED DESIGN $^{\circledR} \quad$ (IRD) procedure. Font recognition through their contours is intended for visual 
spectrum. Authenticity of packaging and forensic approach is secured through infrared effect of IRD method. Example of dedicated halftoning method is presented (Fig. 3).

In twin system coloured lines are engaged, while in this example two colours are engaged. Although the whole area is (multi) coloured, knee shaped system points borders of a specified font. On the fonts place $\mathrm{X}_{40}$ twin colour is introduced. All lines from the various twins have the same $\mathrm{Z}$ value on the font's surface. On places where no font is placed, line colour renders value of $\mathrm{X}_{0}$ twin. In such a way graphic expresses two stages. The font is visible instrumentally via infrared camera as grey line structure, while surrounding of fonts is not manifested by IR capturing. $\mathrm{Z}$ camera records the area outside of font the same way as it records white paper. Lines are not recognised. V camera recognises only font contours generated with the knee effect graphics system.

Invisible $\mathrm{Z}$ graphics as fonts, can be presented as a variety of other designer's concepts, such as portrait, sketch, or computer graphics with complete individual customization or any other idea. IR algorithm merges visual and infrared space in unique graphic arrangement.

Lines can have various graphic arrangements, so they can differ in width, in relation of its coloured area and non-covered-translucent spacing, rotund of a line, direction of the line, part of $\mathrm{Z}$ graphics rotation, irregularities in modelling until causally defined elements in vignette shape, stochastic definition of iterating colour series or choice of the parameters in pseudo-random algorithm.

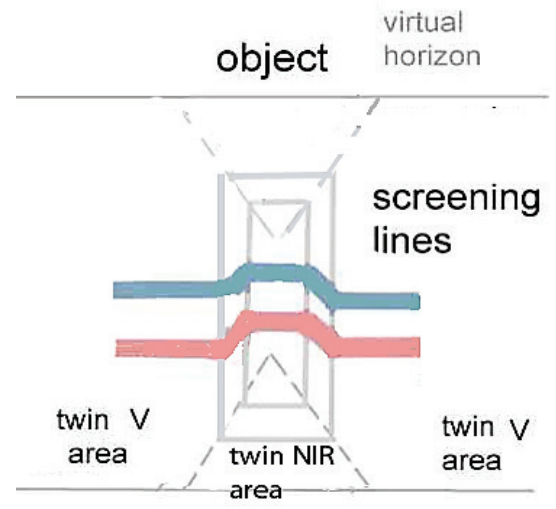

Figure 3 A real effect used for visual object view

Coverage relation between coloured line and noncovered parts, in the whole area of security IR graphics is four to three. Such design is dedicated for transparent polypropylene print packaging for nutrition purposes. Visibility of an article wrapped in such a way is $43 \%$, what is a measure for its recognition. Usage of such system is on pies, meat, bread, juices and similar items. Lines design is planned as the coloured graphics in two stages. On places where font is placed, lines have a response in the infrared spectrum. As additional security option halftoning line can, besides colour changes, own specific programmed (micro)structure attuned for specified product. Such (micro)programmed line can be in any coverage, not only full tone, and in such way the visibility of packed ware is improved (Fig. 4).

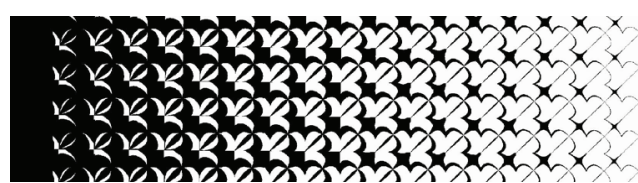

Figure 4 Enlarged image of "structure" (used) programmed halftoning line

Fig. 5 demonstrates the structure of halftoning lines without any additional programming. "Accented" part outlines font or object contour facilitating its recognition, and in the same time defining secondary image placement Any other secondary image can be positioned in any other place. Fonts with text "GRGA" and background are displayed as a structure of parallel lines with continuous changed width and white distances between them.

As in this publication technically high dedicated separation of non-system dyes is not possible, example will be presented as greyscale (Fig. 6).

For printing of $\mathrm{V}$ and $\mathrm{Z}$ graphics on polymer, matted and metalized films or foils can be used, with various properties for various purposes. Barrier films are resistant to oxygen and water vapour access, and metalized films are resistant to light thoroughfare.

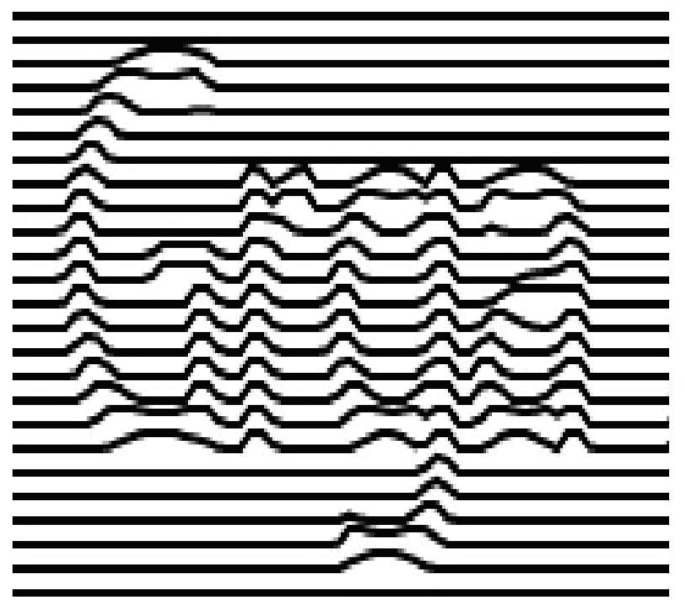

Figure 5 Example of knee effect line screen as presented as solid lines

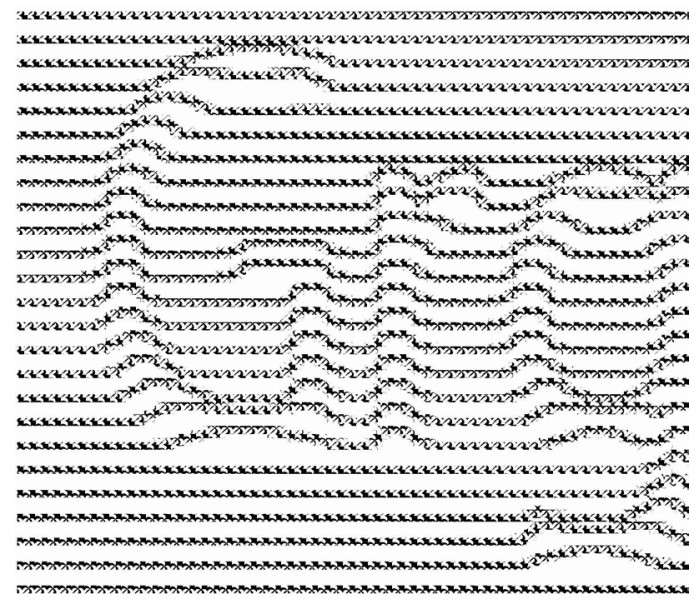

Figure 6 Example as dedicated programmed line knee effect screen with defined coverage

On all mentioned materials-media IRD investigations are performed, where colour parameters are defined. They are strictly dependent on characteristics of the used material, printing equipment and the printing output. It 
means that one halftoning combination of process dyes or spot dyes does not have to be advanced or successful on all other mentioned materials, or in other words, the applied profile is dedicated strictly to selected output system. As an additional security issue, used screening element is not from any standard set. Custom designed element and its partially uncovered structure enables some additional transparency in printed areas, which makes packaged goods more visible.

\section{$4 \quad$ Flexographic output facility specificities}

Flexographic printing is a technique where printing form is made from polymer (rubber) material in 3D relief, and printing elements are elevated (high) as in letterpress system, while nonprinting elements are in level as basiccarrying substrate of the printing form. Commonly used materials in flexo system are polypropylene (Ppbopp), metalized propylene (PPmet), polypropylene cast (Ppcast), polyethylene (PE), polyester (PET), polyamide (PA), aluminium (Al), sleeve films (PET and PVC), paper. With aid of programmed knee effect linearization of a translucent graphics is performed containing of random chosen values CMY inks/dyes and corresponding twins CMYK inks/dyes, but also other non-system inks/dyes twins adjusted, supporting NIR effect and Z image and properties.

Crucial property of any material for IRD printing [13] way-out is its surface tension that should be $38 \div 42$ [dyn $/ \mathrm{cm}$ ] according to ASTM D 2578 method depending on material sort, stretching ability of the film (if it exists), which should be as low as possible (measured as percentage $\pm 5 \%$ ), so that separations can be easier integrated and covered together.

$\mathrm{V}$ and $\mathrm{Z}$ inks from tanks pump, forced under pressure, are transferred alongside Anilox roller into chamber. Ink excess from roller is removed with razor blade, so defined ink amount stays in accordance to roller ruling and dimples, known as cells depth. Characteristics, including Anilox roller ruling, are set up according to quality and print demands. Every job has to be defined with correct roller coverage, to avoid printing form (over)filling, porosity of ink layer, or low saturation caused by low ink layer.

Printing substrate (etiquette, label, polypropylene) passes between printing and underlying cylinder rotating in back to back order, with different perimeter velocities, and after each separation print is dried with hot air (blower temperature $50 \div 80{ }^{\circ} \mathrm{C}$ ) before next separation printing. Final drying, after printing all separations, occurs in main tunnel. Temperature for $400 \mathrm{~m} / \mathrm{min}$ speed is $60{ }^{\circ} \mathrm{C}$, and $45{ }^{\circ} \mathrm{C}$ is for $100 \mathrm{~m} / \mathrm{min}$. Temperature is changed in accordance of printing speed, ink layer and used printing substrate. During the printing there is no possibility of $Z$ graphics recognition, and printing each separation separately hidden Z-graphic cannot be recognised.

Secondary (NIR) image is defined with twin pairs [14]. Several coloured screen lines are established, rather low ruling, that repeat in a cyclic way, covering the entire graphic. Each particular line is performed as a defined twin describing primary-visual object or text.

\section{Twin line pairs}

As stated, this NIR technology system performs series of programmed coloured twin lines. Defined series of coloured lines repeat cyclically covering the whole area of predicted graphic. Primary-visual graphic is made as the line text with "knee" effect, and secondary graphic, that will be observed in NIR domain is performed as a twin.

For operational printing realisation, separate palette inks mixture for each of four twin pairs is provided. Basic twin pair inks are produced as a defined mixture within proved and known independent set-up environment. All components have to be proved for $\mathrm{V}$ and $\mathrm{Z}$ specification.

On grounds of additional security reasons, chosen operational mixed inks (properties) were recalculated to standard CMYK inks/dyes, and were used only in testing and proofing conditions. As an example (applying high dedicated system profile), for the first line twin pair is defined (Fig. 7, Fig. 9) and spectrophotometric curves, (Fig. 8, Fig. 10). Spectrograms were measured with forensic instrument ProjectinaDocucenter 4500, Projectina AG, Switzerland.

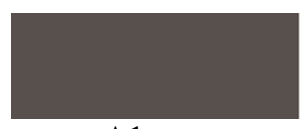

A1

Figure 7 Twin pair (A1) and (A2)

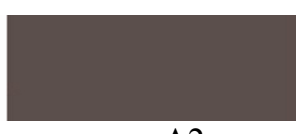

A2
Twin pair (A1) and (A2) have the following measured values:

A1: (V twin): L*a*b*: 33-1-5

recalc. Coverage (â) 80-80-80-0

A2: (NIR twin) L*a*b*: 32-2-6

recalc. Coverage (â) 53-56-55-40

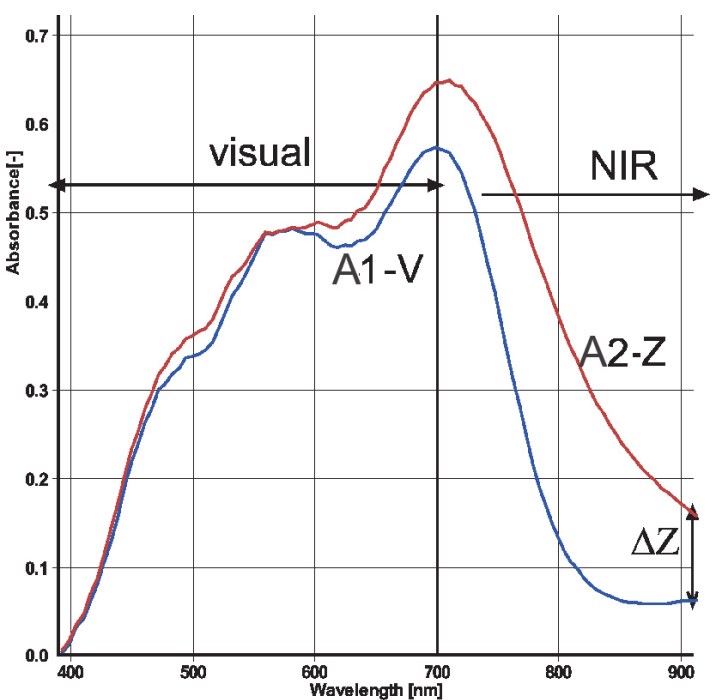

Figure 8 Example of spectral curves of (A1) and (A2) twin pair in V and NIR domain

If observed visually (A) pair (neutral greyish), fits, regardless to its composition. In visual part $(400 \div 700 \mathrm{~nm})$ they partially overlap, one has an expressed absorption peak about $550 \mathrm{~nm}$. Region $700 \div 800 \mathrm{~nm}$ is resolving with no mutual influence, leading to clearly disjointed $\mathrm{Z}$ region. 
For (B) pair (dark reddish), both have expressed absorption at $500 \mathrm{~nm}$ and $600 \mathrm{~nm}$ and about $700 \mathrm{~nm}$ separate (Fig. 10). Distinguishing area till $800 \mathrm{~nm}$ is evident, leading to disjointed area of $\mathrm{Z}$ domain. Achieved difference for both twins in $Z$ domain is sufficient for instrumental NIR reading.

In proposed surrounding one twin has $\mathrm{Z}$ value (near) zero, while the second twin shows $\Delta \mathrm{Z}$ difference of 0,1 and 0,2 or more, in accordance with the first for dependency of NIR reflection.

It is possible to perform (mix) a huge number if twin pairs with adequate $\mathrm{V}$ and $\mathrm{Z}$ properties. In the visual part all twin pairs achieve the same spectral characteristics, but differ in NIR domain. Differentiation starts between $700 \div 800 \mathrm{~nm}$, and above $800 \mathrm{~nm}$ twins arrange concerning to carbon black amount. This stage is defined through $\mathrm{Z}$ parameter [15]. Visual and colorimetric twins (A) and (B) are unifying. Color difference for twin pair A (A 1-2) $\Delta \mathrm{E}_{76}$ is 1.73 and pair $\mathrm{B}(\mathrm{B} 1-2)$ is $\Delta \mathrm{E}_{76} 4.10$, that is acceptable/suitable. It must be noticed that this example is highly dedicated, and profile corresponds to flexo/propylene output system.

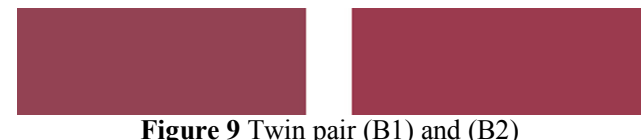

Twin pair (B1) and (B2) have the following measured values:

B1: V twin L*a*b*: 38-36-10

recalculated Coverage (â) 50-90-70- 0

B2: NIR twin L*a*b*: 36-33-12

recalculated Coverage (â) 3-78-37-40

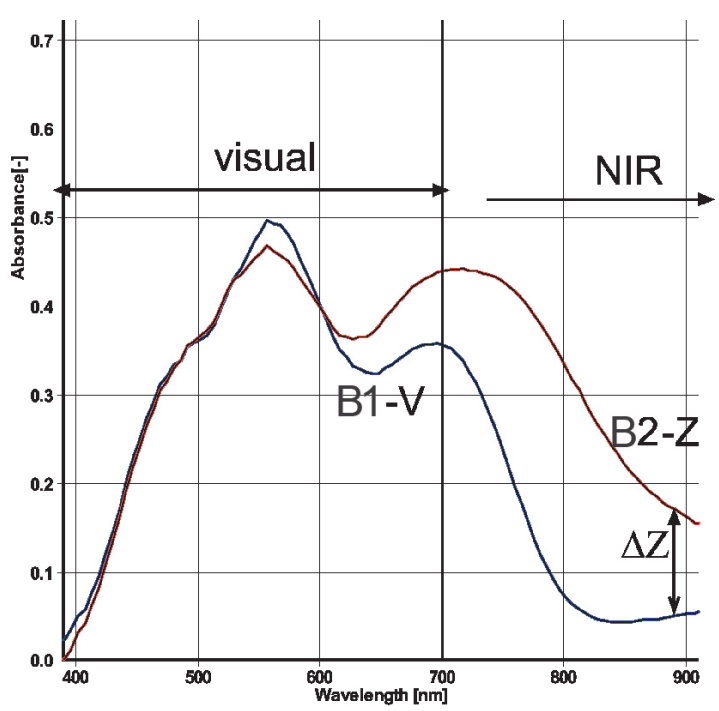

Figure 10 Example of spectral curves of (B1) and (B2) twin pairs in V and NIR domain

\section{Conclusions}

Line transparent halftoning approach with "knee" effect appears to be suitable for certain combinations of visual/NIR imaging reproductions. Polypropylene material/medium in combination with IRD experiences affirmation, acknowledgement and new printing method concept, hiding approach, printing in a way for achieving graphic beyond visual spectrum, dual images existence, transparency printing, visual and instrumental verification.

"Line" from line screen is possible to adapt, change and manipulate the programme, and as in demonstrated case achieving knee shape, presenting reasonable areal effect for primary-visual graphic or object. Secondary, NIR image-graphic is performed trough twin pairs system for each line, and will be detected in $\mathrm{Z}$ imaging system [15]. This line system can be useful for graphics and certain objects (as bar code), at non-standard and demanding printing materials, such as transparent substrates and/or various special features.

This adopted reproduction workflow containing multiple security features involving extended NIR technology, custom defined twin pairs inks, specially designed screening and element shape and structure, with flexo printing on transparent foil, ensures imposed security on multiple levels: publishers, designers and printing production. Broaden inks mixing, extended prepress procedures, controlled penetration of inks led to extended output reproduction and printing facilities. Innovations in flexoprinting and usage of propylene substrates include twin dyes, $\Delta \mathrm{Z}$ values, visual and instrumental testing, and response in near infrared domain.

That wide range security realization system can be implemented in a wide palette of materials and systems [16], and programmed halftoning-screening provides a wide range of designer's arrangements with demanding substrates, packaging, transparent systems, and nonstandard materials.

\section{References}

[1] Žiljak, V.; Pap, K.; Žiljak-Stanimirović, I. Development of a Prototype for ZRGB Infraredesign Device. // Technical Gazette. 18, 2(2011), pp. 153-159.

[2] Li, C.; Wang, C.; Wang, S. J. A Black Generation Method for Black Ink Hiding Infrared Security Image. // Applied Mechanics and Materials, Trans Tech Publications, Switzerland. 262, (2013), pp. 9-12.

[3] Kondratov, A. P. Thermo Shrink Films with Interval Macrostructure for Protection of Packaging from Falsification. // Modern Applied Science. 8, 6(2014), pp. 204-209. DOI: 10.5539/mas.v8n6p204

[4] Suyoto, L.; Widyastuti, K.; Ardhinugroho, L. The Algorithm to Detect Color Gradation on Silk. // IJCSI International Journal of Computer Science Issues. 9, 2(2012), pp. 176-180. (27.9. 2015)

[5] Heesang, S.; Napoleon, H. R.; Barczak, A. L. Colour Object Classification Using the Fusion of Visible and NearInfrared Spectra. // Trends in Artificial Intelligence, $11^{\text {th }}$ Pacific Rim International Conference on Artificial Intelligence, Daegu, Korea, August 30 - September 2, 2010. Proceedings, pp. 498-505.

[6] Žiljak Vujić, J.; Žiljak Stanimirović,I.; Bjelovučić Kopilović, S.; Friščić, M. Zaštita prozirne savitljive plastične ambalaže postupkom Infraredesign ${ }^{\circledR}$. // Polimeri: časopis za plastiku i gumu. 34, 10(2013), pp. 42-46.

[7] Chromograph DC 399: Operation manual, Dr. Ing. R. Hell, Kiel, 1985, Ch. IV.

[8] Morgenstern, D. Rasterungtechnik, Polygraph Verlag, Frankfurt a.M, 1985.

[9] Žiljak, J.; Kropar - Vančina, V.; Agić, D.; Žiljak, I.; Pap, K. New screening elements in multi-colour printing for specialpurposes. // Advances in printing science and 
technology, Proceedings of the $30^{\text {th }}$ International Research Conference of the International Association of Organizations for the Printing, Information and Communication Industries IARIGAI, Zagreb: Acta Graphica Publishers / Cavtat, 2003, pp. 143-150.

[10] Žiljak, I.; Pap, K.; Agić, D. Behaviour of Some Custom Programmed Screening Elements in Various Printing Systems. // Proceedings of the $32^{\text {nd }}$ International IARIGAI Research Conference Papers, Porvoo, The International Association of Research Organisations for Printing, Information and Communication Industries VTT Technical Research Centre of Finland (2005.), pp. 175-179.

[11] American National Standards Institute. Standard Test Method for Wetting Tension of Polyethylene and Polypropylene Films. ISO 8296 Plastics -Film and Sheeting - Determination of Wetting Tension Available from American National Standards Institute (ANSI), 25 W. 43rd St., 4th Floor, New York, NY 10036, http://www.ansi.org. (10.2015)

[12] Pap, K.; Žiljak Vujić, J.; Žiljak, I. Design of Digital Screening, FS, Zagreb, 2008.

[13] Žiljak, V.; Pap, K.; Žiljak, I. CMYKIR Security Graphics Separation in the Infrared Area. // Infrared Physics and Technology. 52, 2-3(2009.), pp. 62-69.

[14] Agić, D.; Agić, A.; Bernašek, A. Blizanci bojila za proširenje infra informacijske tehnologije. // Polytechnic and Design. 1, 1(2013), pp. 27-32.

[15] Žiljak, V.; Pap, K.; Žiljak-Stanimirović, I.; Žiljak-Vujić, J. Managing dual color properties with the Z-parameter in the visual and NIR spectrum. // Infrared physics \& technology. 55, (2012), pp. 326-336. DOI: 10.1016/j.infrared.2012.02.009

[16] Agić, A.; Žiljak Vujić, J.; Agić, D. Metoda namjenskog podešavanja za dvojne boje - nužni postupak za vizualnu i NIR sliku. Twin Colors Mode Dedicated Adjustment Necessity for Visual and Nir Image. // Polytechnic and Design. 3, 2(2015), pp. 170-174.

\section{Authors' addresses}

Friščić Martina, MS, postgraduate

University of Zagreb, Faculty of Graphic Arts, Getaldićeva 2, Zagreb, Croatia

E-mail: martina.friscic@rotoplast.hr

E-mail: martina.friscic@gmail.com

Agić Ana, MS, postgraduate

University of Zagreb, Faculty of Graphic Arts, Getaldićeva 2, Zagreb, Croatia

E-mail: ana.agic@grf.hr

E-mail: ana_agic@yahoo.com

Žiljak Stanimirović Ivana, dr. sc, associate professor

University of Zagreb, Faculty of Graphic Arts,

Getaldićeva 2, Zagreb, Croatia

E-mail: ivana.ziljak@grf.hr

E-mail: ivana.ziljak.stanimirovic@gmail.com 